Published in final edited form as:

Surg Oncol Clin N Am. 2015 July ; 24(3): 491-508. doi:10.1016/j.soc.2015.03.006.

\title{
CANCER OF THE ORAL CAVITY
}

\author{
Pablo H. Montero, MD* and Snehal G. Patel, MD* \\ "Head and Neck Surgery Service, Department of Surgery, Memorial Sloan-Kettering Cancer \\ Center
}

\section{Keywords}

oral cavity cancer; oral cancer; squamous cell carcinoma; head and neck cancer

\section{INTRODUCTION}

Cancer of the oral cavity is one of the most common malignancies, ${ }^{1}$ especially in developing countries, but also in the developed world ${ }^{2}$. Squamous cell carcinoma (SCC) is the most common histology and the main etiological factors are tobacco and alcohol use ${ }^{3}$. Although early diagnosis is relatively easy, presentation with advanced disease is not uncommon. The standard of care is primary surgical resection with or without postoperative adjuvant therapy. Improvements in surgical techniques combined with the routine use of postoperative radiation or chemoradiation therapy have resulted in improved survival statistics over the past decade ${ }^{4}$. Successful treatment of patients with oral cancer is predicated on multidisciplinary treatment strategies to maximize oncologic control and minimize impact of therapy on form and function.

\section{ANATOMY OF THE ORAL CAVITY}

The oral cavity extends from the vermilion border of the lips to the circumvallate papillae of the tongue inferiorly and the junction of the hard and soft palate superiorly. The oral cavity is divided into several anatomical subsites: lip, oral tongue, floor of mouth, buccal mucosa, upper and lower gum, retromolar trigone and hard palate (Figure 1). Despite their proximity, these subsites have distinct anatomical characteristics that need to be taken into account in planning oncologic therapy.

\section{EPIDEMIOLOGY AND ETIOLOGY}

Worldwide, 405,000 new cases of oral cancer are anticipated each year, and the countries with the highest rates are Sri Lanka, India, Pakistan, Bangladesh, Hungary and France ${ }^{5}$

Corresponding Author: Dr. Snehal G. Patel, Head and Neck Surgery, Memorial Sloan-Kettering Cancer Center, 1275 York Ave, New York, NY 10065. Telephone: 212-639-3412, patels1@ mskcc.org.

The Authors have nothing to disclose.

Publisher's Disclaimer: This is a PDF file of an unedited manuscript that has been accepted for publication. As a service to our customers we are providing this early version of the manuscript. The manuscript will undergo copyediting, typesetting, and review of the resulting proof before it is published in its final citable form. Please note that during the production process errors may be discovered which could affect the content, and all legal disclaimers that apply to the journal pertain. 
(Figure 2). In the European Union there are an estimated 66,650 new cases each year. The American Cancer Society estimates that there will be 42,440 new cancers of the oral cavity and pharynx in the U.S. causing 8,390 deaths in $2014^{6}$. Tobacco smoking and alcohol are the main etiological factors in SCC of the oral cavity $(\mathrm{SCCOC})^{3,7}$. Other habits such as betel nut and tobacco chewing have been implicated in the Asian population.

Tobacco contains many carcinogenic molecules, especially polycyclic hydrocarbons and nitrosamines. A directly proportional effect exists between the pack years of tobacco used and the risk of $\mathrm{SCCOC}^{8}$. This risk can be reduced after tobacco cessation, but it does not fully abate (30\% in the first 9 years and $50 \%$ for those over 9 years $)^{910}$. A decreased incidence of oral cavity cancer has been reported in the last 15 years, widely attributed to a reduction in tobacco use ${ }^{11}$.

Alcohol and tobacco seem to have a synergistic effect in the etiology of oral and oropharyngeal $\mathrm{SCC}^{3,12,13}$. However, alcohol is linked to an increased risk of cancer even in non-smokers ${ }^{14}$. Other factors such as poor oral hygiene ${ }^{15}$, wood dust exposure ${ }^{16}$, dietary deficiencies ${ }^{17}$, red meat and salted meat consumption ${ }^{18,19}$ have been reported as etiologic factors. The herpes simplex virus (HSV) has been suspected but has not been implicated in the etiology of $\mathrm{SCCOC}^{20}$. Despite the emerging evidence supporting the role of the human papilloma virus (HPV) in the etiology of oropharyngeal cancer, it has not been conclusively linked to $\mathrm{SCCOC}^{21}$. Host factors such as immune system alterations in transplant patients $^{22,23}$ and HIV-infected patients with $\operatorname{AIDS}^{24}$, and genetic conditions like xeroderma pigmentosum, Fanconi anemia and ataxia telangiectasia are associated with an increased incidence of head and neck cancer ${ }^{25-28}$.

Oral cancer is more common in men and usually occurs after the $5^{\text {th }}$ decade of life. About $1.5 \%$ will have another synchronous primary in the oral cavity or the aero-digestive tract (larynx, esophagus or lung) ${ }^{29}$. Metachronous tumors develop in $10 \%$ to $40 \%$ in the first decade after treatment of the index primary ${ }^{30,31}$ and therefore regular post-therapy surveillance and lifestyle alteration are important strategies for secondary prevention.

\section{PATHOLOGY}

Squamous cell carcinomas (SCC) constitute more than $90 \%$ of all oral cancer. Other malignant tumors can arise from the epithelium, connective tissue, minor salivary glands, lymphoid tissue, and melanocytes or metastasis from a distant tumor.

A variety of premalignant lesions have been associated with development of $\mathrm{SCC}^{32}$. The more common premalignant lesions including leukoplakia, erythroplakia, oral lichen planus, and oral submucous fibrosis have varying potential for malignant transformation ${ }^{33}$. The WHO (2005) classifies premalignant lesions according to degree of dysplasia into mild, moderate, severe, and carcinoma in situ.

Leukoplakia is a clinical term defined as a "white patch or plaque that cannot be characterized clinically or pathologically as any other disease" 34 . This lesion is usually associated with smoking and alcohol use. The prevalence of leukoplakia worldwide is about $2 \%$. Dysplastic changes are seen in only $2-5 \%$ of patients. The annual rate of malignant 
transformation for leukoplakia is $1 \%$. Risk factors for malignant transformation include presence of dysplasia, female gender, long duration of leukoplakia, location on the tongue or floor of mouth, leukoplakia in non-smokers, size greater than $2 \mathrm{~cm}$, and non-homogeneous type. In addition to lifestyle alteration to avoid tobacco and alcohol use, excision constitutes the only definitive modality for accurate diagnosis and treatment.

Erythroplakia is a "bright red velvety patch that cannot be characterized clinically or pathologically as being caused by any other condition" 34 . Surgical excision is recommended as these lesions have higher malignant potential than leukoplakia and are commonly associated with dysplasia and carcinoma in situ.

Non-squamous cell carcinomas of the oral cavity are uncommon. Minor salivary gland carcinomas represent less than 5\% of the oral cavity cancers. They frequently arise on the hard palate $(60 \%)$, lips $(25 \%)$ and buccal mucosa $(15 \%)^{35}$. Mucoepidermoid carcinoma is the most common type (54\%), followed by low-grade adenocarcinoma (17\%), and adenoid cystic carcinoma $(15 \%)^{49,50}$.

Mucosal melanomas are rare but usually present as locally aggressive tumors, mainly of the hard palate and gingiva. Bony tumors including osteosarcoma of the mandible or maxilla and odontogenic tumors such as ameloblastoma can present within the oral cavity and may be mistaken for a mucosal lesion if there is surface ulceration.

\section{CLINICAL PRESENTATION AND EVALUATION}

Despite easy self-examination and physical examination, patients often present with advanced stage disease. A comprehensive head and neck exam is mandatory in patients with suspected oral cavity cancer. Visual inspection and palpation allow an accurate impression of the extent of the disease, the third dimension of tumor, the presence of bone invasion, or skin breakdown. Appropriate documentation with drawings and photographic records of the tumor are useful in staging, decision-making and further follow up.

The clinical TNM stage should be recorded at first encounter and modified as evaluation progresses. The initial workup consists of diagnosis by biopsy. Accessible lesions may be adequately biopsied in the clinic using punch forceps, core needle or fine-needle aspiration. Some patients will require examination under general anesthesia (EUA) in order to access posteriorly located lesions, or to complete a physical exam limited by pain and trismus. Radiographic imaging is crucial for evaluation of the relation of the tumor to adjacent bone and for assessing regional lymph nodes. CT scan is the study of choice for evaluation of bone and neck nodes, especially early cortical involvement and extracapsular nodal spread. MRI provides complementary information about soft tissue extent and perineural invasion and is also helpful for evaluating the extent of medullary bone involvement because adult marrow is normally replaced by fat. Most patients with oral cancer are not at risk for distant metastases and therefore the role of PET scan in initial assessment is debatable. However, a preoperative PET scan may be useful as a baseline if adjuvant treatment is anticipated and a PET scan will be used for radiation therapy planning (though this is undertaken differently from a "diagnostic" PET scan). Patients with locally advanced tumors require appropriate 
multidisciplinary consultations with the reconstructive surgeon, medical specialists for presurgical optimization, dental professionals, speech and swallowing pathologists, and behavioral therapists for smoking cessation and other lifestyle alterations.

The TNM system is the most widely accepted prognostic system due to its relatively simple design and user-friendliness. The clinical staging of the oral cavity tumors consists of primary tumor characteristics, the neck, and assessment for distant metastases (Table 1). This information allows TNM stage grouping for the tumor (Table 2$)^{36}$. The basic elements in staging of the primary site are the tumor size and invasion of deep structures. Advanced disease is defined by invasion of structures such as medullary bone, deep muscle of the tongue, maxillary sinus, and skin for T4a disease, or masticator space, pterygoid plates, or skull base and/or encasement of the internal carotid artery for T4b disease. Lymphatic spread into the neck generally occurs in a step-wise, orderly and predictable fashion. The lymph node echelons of the neck are described using the terminology standardized by the American Head and Neck Society Guidelines ${ }^{37}$ (Figure 3).

Knowledge of the patterns of nodal metastasis has practical implications in the design of neck dissection for patients with oral cancer. The patient with a clinically negative neck is at highest risk of metastasis to levels I-III ${ }^{38}$. Skip metastases to level IV do occur, especially in cancer of the anterior tongue. Metastases to level V are extremely rare (1\%) even in patients with clinically positive neck. Oral tongue tumors have the greatest propensity of all oral cancers for metastasis to the neck, and tumor thickness (Figure 4) is a major predictor of risk of nodal metastasis ${ }^{39}$.

\section{TREATMENT}

Surgical resection is the treatment of choice for SCCOC. Surgical resection allows accurate pathologic staging, with information about the status of margins, tumor spread and histopathologic characteristics which can then be used to inform subsequent management based upon assessment of risk versus benefit. Adjuvant radiotherapy \pm chemotherapy is used for specific indications in locoregionally advanced tumors. A multidisciplinary team is absolutely essential to ensure a favorable outcome. Multiple factors are taken into account in selecting treatment for an individual patient. The risk of treatment-related complications should be assessed based on physiological age, comorbid conditions (e.g. cardiopulmonary status), lifestyle (smoking or alcohol), surgical resectability, and patient expectations.

\section{Surgical Management}

A detailed description of surgical technique for management of oral cavity cancers is beyond the scope of this publication and the reader is referred to specialized texts for this information ${ }^{40}$. Broad principles of surgical management will be discussed and these include access to the oral cavity, management of the mandible, management of neck nodes, and reconstruction of oral cavity surgical defects.

Surgical access-The transoral approach is usually used for premalignant lesions and small, superficial tumors of the anterior floor of mouth, alveolus and tongue. A more invasive approach becomes necessary for posteriorly located tumors or if there are 
limitations due to trismus or inadequate surgical exposure (Figure 5). The lip-splitting paramedian mandibulotomy approach is used for larger posteriorly located tumors of the tongue. The upper cheek flap and midfacial degloving approaches are useful for gaining access to the maxilla.

Management of the mandible-Mandibular invasion can occur early in tumors of the floor of the mouth, the ventral surface of the tongue and the gingivobuccal sulcus. The mechanism of invasion of these tumors into the mandible has been well studied ${ }^{41-43}$. Tumors invade the mandible through the dental sockets in the dentate mandible, and through the dental pores of the alveolar process in the edentulous mandible.

Early cortical invasion of the mandible is difficult to assess with plain radiography, or orthopantomograms but CT scans are more sensitive. On a practical basis, tumors that are in close juxtaposition to the mandibular cortex will require consideration for marginal mandibulectomy in order to achieve an adequate margin of resection irrespective of radiographically demonstrable early cortical invasion. The role of marginal resection might be limited in patients with reduced vertical height of the body of the mandible due to the higher risk of early involvement of the body of mandible and the risk of pathologic fracture if a marginal resection is performed. Adequate tumor clearance in edentulous patients may therefore necessitate a segmental mandibulectomy. The indications for segmental resection are listed in Table 3.

Management of the neck-Sixty percent of patients with early stage oral cancer will present with a clinically negative neck (cN0). Approximately 20-30\% will have microscopically evident nodal metastasis on histologic examination after elective neck dissection (END). The risk of nodal metastasis is related to several factors (Table 4) 44,45 . Cervical lymph node metastasis is the single most important prognostic factor in oral cancer: survival chances are reduced by $50 \%$ when compared to those with similar primary tumors without neck metastases ${ }^{46,47}$. SCC of the oral tongue and the floor of the mouth are more likely to metastasize to the neck, and these patients should be offered END, even for early stage tumors, if they are thicker than about $4 \mathrm{~mm}^{48}$. The hard palate and the upper gum have a relatively lower rate of occult nodal metastasis and END may not be indicated ${ }^{49}$.

Sentinel node biopsy is an alternative to END for staging the cN0 neck in early stage (T1-2) SCCOC. The technique was first reported in 2001 by Shoaib et al ${ }^{50}$ and has been analyzed in several single institutional studies as well as two prospective multicenter trials, one in Europe $^{51,52}$ and the other in the US ${ }^{53}$. The procedure is technically challenging and successful identification of sentinel nodes and detecting occult metastasis depends on expertise and experience. Therefore, it should be undertaken only in centers with the necessary proficiency and the appropriate volume of $\operatorname{cases}^{54}$.

In patients with clinically or radiographically involved neck nodes, a therapeutic comprehensive neck dissection is indicated (Table 5). It involves dissection of levels I to V. The need to sacrifice other structures such as the spinal accessory nerve, sternocleidomastoid muscle, or internal jugular vein depends on the location of the metastasis and its characteristics. The most common type of comprehensive neck dissection 
is the modified radical neck dissection, MRND Type 1. Radical neck dissection is rarely performed unless there is direct infiltration of the relevant structures by gross extranodal extension of disease (Table 5).

In a patient with a clinically negative neck, the risk of occult metastasis is mainly to levels I through III. Potential compromise of levels IV and V is very rare. For these reasons, a supraomohyoid neck dissection (SOHND)(Table 5) is usually adequate to stage the cN0 neck. In patients with primary oral tongue SCCOC dissection of level IV may be indicated due to the possibility of skip metastasis. For patient with positive nodes on END, neck recurrence is observed in $10-24 \% 55$. Appropriately selected patients benefit from postoperative radiation therapy ${ }^{56,57}$. For $\mathrm{cN}_{0}$ patients who are proven pathologically $\mathrm{N}_{0}$, failure rates of less than $10 \%$ have been reported ${ }^{58}$.

Reconstructive surgery-Restoration of form and function after ablative cancer surgery is the ultimate goal of treatment and is achieved by choosing the appropriate reconstructive procedure. Surgical defects after resection of early stage tumors can usually be reconstructed with primary closure or the use of skin graft or skin substitutes. Reconstruction of larger and more complex defects that result from resection of advanced tumors requires participation from an expert reconstructive surgeon. Microvascular free tissue transfer is the technique of choice $^{59,60}$. For example, in patients with soft tissue defects of the oral tongue, floor of mouth and retromolar trigone, the free radial forearm flap results in excellent functional results (Figure 6). In addition to soft tissue cover, free flaps are also a reliable source for bone reconstruction. The fibula free flap is currently the workhorse in reconstruction of defects following segmental mandibulectomy (Figure 6). Other composite microvascular flaps include the radial forearm osteocutaneous flap, iliac crest and scapula free flaps. Several studies have demonstrated the reliability and low morbidity of microvascular free flap reconstruction techniques ${ }^{61}$. The ability reliably to reconstruct large surgical defects has contributed to improved oncologic outcomes in patients with locally advanced cancers by enabling more complete resections ${ }^{62}$. Pedicled myocutaneous flaps such as the pectoralis major, latissimus dorsi or trapezius flaps are reliable alternatives if surgical expertise is not available or if the patient is not a good candidate for microvascular reconstruction.

\section{Adjuvant treatment}

Adjuvant postoperative treatment is indicated in patients with high risk of locoregional recurrence. This includes patients with large primary tumors (pT3 or pT4), bulky nodal disease ( $\mathrm{pN} 2$ or $\mathrm{pN} 3$ ), metastases to nodal levels IV or V, positive surgical margins, lymphovascular invasion, perineural invasion, and extracapsular spread. External beam radiation therapy has been the traditional modality for postoperative adjuvant treatment and doses of 66-70 Gy result in good locoregional control ${ }^{63}$, 64. Two clinical trials have shown that administration of cisplatin chemotherapy concurrently with postoperative radiotherapy improves locoregional control and survival (versus radiotherapy alone) in head and neck cancer patients with extracapsular spread and /or positive surgical margins ${ }^{65}$, 66 . However, concurrent chemoradiation can result in significant morbidity and is best used at centers where appropriate expertise and infrastructure is available. 


\section{OUTCOMES OF TREATMENT}

The results of treatment of SCCOC in recently published major series are shown in Table 6. The overall 5-year survival in a recently analyzed cohort of patients at Memorial SloanKettering Cancer Center is 63\%. This represents a significant improvement compared to historical cohorts (Figure 7) and may be related to wider use of microvascular free flaps with enhanced ability to resect large tumors and reconstruct large and complex defects, more aggressive regional therapy including increasing use of elective selective neck dissections, and the use of postoperative adjuvant therapy.

Approximately a third of patients treated for SCCOC relapse, and locoregional recurrence is the most common pattern of failure. The clinical stage at presentation is an important predictor of survival (Figure 8) but the most powerful predictor of outcome is the presence of metastatic lymph nodes (Figure 9). Other clinical signs of locally advanced disease and poor prognosis include trismus, which indicates invasion of the pterygoid, temporalis or masseter muscle; reduced tongue mobility, which indicates invasion of the extrinsic musculature of the tongue or the hypoglossal nerve; and skin invasion with dermal lymphatic infiltration. Significant histopathologic predictors of outcome include depth of invasion of the primary tumor, positive margins of surgical resection, perineural invasion and major extracapsular nodal extension.

\section{Follow up}

Oral cancer patients have a high risk of locoregional recurrence and developing subsequent new primary cancers, but the risk of distant recurrence is $\operatorname{low}^{67}$. The possibility of a second head and neck primary is about $4-7 \%$ a year and comprehensive clinical examination and a high suspicion are the cornerstones of early diagnosis ${ }^{68}$. Control of lifestyle-related risk factors, such as tobacco and alcohol consumption, is a priority in these patients because of the higher risk of treatment failure and second primaries ${ }^{69}$. Unfortunately, there is no effective chemoprevention and close follow up remains the most important tool in secondary prevention ${ }^{70}$. Baseline imaging studies are often obtained about 3-6 months following completion of treatment and then as needed based on clinical suspicion. Chest imaging is not routinely needed but may be beneficial in patients with a significant smoking history. Other ancillary measures include speech and swallowing rehabilitation as indicated, monitoring of thyroid stimulating hormone levels if the neck been treated with radiation therapy, and regular dental evaluation.

\section{CONCLUSION}

Treatment results for patients with oral cancer have improved considerably over the last several decades due to improvements in reconstruction and adjuvant treatment. Further improvements in survival have been hampered by attrition from second and subsequent primary tumors in long-term survivors. Primary and secondary prevention of oral cancer requires better education about lifestyle related risk factors, and improved awareness and tools for early diagnosis. 


\section{References}

1. Jemal A, Bray F, Center MM, et al. Global Cancer Statistics. Ca-Cancer J Clin. 2011; 61(2):69-90. [PubMed: 21296855]

2. Siegel R, Naishadham D, Jemal A. Cancer statistics, 2013. Ca-Cancer J Clin. 2013; 63(1):11-30. [PubMed: 23335087]

3. Blot WJ, McLaughlin JK, Winn DM, et al. Smoking and drinking in relation to oral and pharyngeal cancer. Cancer research. 1988; 48(11):3282-3287. [PubMed: 3365707]

4. Pulte D, Brenner H. Changes in survival in head and neck cancers in the late 20th and early 21 st century: a period analysis. The oncologist. 2010; 15(9):994-1001. [PubMed: 20798198]

5. Ferlay J, Shin HR, Bray F, et al. Estimates of worldwide burden of cancer in 2008: GLOBOCAN 2008. International journal of cancer Journal international du cancer. 2010; 127(12):2893-2917. [PubMed: 21351269]

6. Siegel R, Ma J, Zou Z, et al. Cancer statistics, 2014. CA: a cancer journal for clinicians. 2014; 64(1):9-29. [PubMed: 24399786]

7. Blot WJ. Alcohol and cancer. Cancer research. 1992; 52(7 Suppl):2119s-2123s. [PubMed: 1544150]

8. Spitz MR, Fueger JJ, Goepfert H, et al. Squamous cell carcinoma of the upper aerodigestive tract. A case comparison analysis. Cancer. 1988; 61(1):203-208. [PubMed: 3334949]

9. Macfarlane GJ, Zheng T, Marshall JR, et al. Alcohol, tobacco, diet and the risk of oral cancer: a pooled analysis of three case-control studies. European journal of cancer Part B, Oral oncology. 1995; 31B(3):181-187.

10. Samet JM. The health benefits of smoking cessation. The Medical clinics of North America. 1992; 76(2):399-414. [PubMed: 1548968]

11. Howlader, NNA.; Krapcho, M.; Neyman, N.; Aminou, R.; Waldron, W.; Altekruse, SF.; Kosary, CL.; Ruhl, J.; Tatalovich, Z.; Cho, H.; Mariotto, A.; Eisner, MP.; Lewis, DR.; Chen, HS.; Feuer, EJ.; Cronin, KA.; Edwards, BK., editors. SEER Cancer Statistics Review, 1975-2008. National Cancer Institute; Bethesda, MD: 2011. http://seercancergov/csr/1975_2008/, based on November 2010 SEER data submission, posted to the SEER web site 2011

12. McCoy GD, Wynder EL. Etiological and preventive implications in alcohol carcinogenesis. Cancer research. 1979; 39(7 Pt 2):2844-2850. [PubMed: 376126]

13. Brugere J, Guenel P, Leclerc A, et al. Differential effects of tobacco and alcohol in cancer of the larynx, pharynx, and mouth. Cancer. 1986; 57(2):391-395. [PubMed: 3942973]

14. Kato I, Nomura AM. Alcohol in the aetiology of upper aerodigestive tract cancer. European journal of cancer Part B, Oral oncology. 1994; 30B(2):75-81.

15. Maier H, Zoller J, Herrmann A, et al. Dental status and oral hygiene in patients with head and neck cancer. Otolaryngol Head Neck Surg. 1993; 108(6):655-661. [PubMed: 8516003]

16. Schildt EB, Eriksson M, Hardell L, et al. Occupational exposures as risk factors for oral cancer evaluated in a Swedish case-control study. Oncology reports. 1999; 6(2):317-320. [PubMed: 10022996]

17. La Vecchia C, Tavani A, Franceschi S, et al. Epidemiology and prevention of oral cancer. Oral Oncol. 1997; 33(5):302-312. [PubMed: 9415327]

18. Tavani A, Gallus S, La Vecchia C, et al. Diet and risk of oral and pharyngeal cancer. An Italian case-control study. European journal of cancer prevention : the official journal of the European Cancer Prevention Organisation. 2001; 10(2):191-195.

19. De Stefani E, Boffetta P, Ronco AL, et al. Processed meat consumption and risk of cancer: a multisite case-control study in Uruguay. British journal of cancer. 2012; 107(9):1584-1588. [PubMed: 23011480]

20. Larsson PA, Edstrom S, Westin T, et al. Reactivity against herpes simplex virus in patients with head and neck cancer. International journal of cancer Journal international du cancer. 1991; 49(1): 14-18. [PubMed: 1651906] 
21. Sturgis EM, Cinciripini PM. Trends in head and neck cancer incidence in relation to smoking prevalence: an emerging epidemic of human papillomavirus-associated cancers? Cancer. 2007; 110(7):1429-1435. [PubMed: 17724670]

22. Lishner M, Patterson B, Kandel R, et al. Cutaneous and mucosal neoplasms in bone marrow transplant recipients. Cancer. 1990; 65(3):473-476. [PubMed: 2297638]

23. Shah AT, Wu E, Wein RO. Oral squamous cell carcinoma in post-transplant patients. American journal of otolaryngology. 2013; 34(2):176-179. [PubMed: 23332408]

24. Ficarra G, Eversole LE. HIV-related tumors of the oral cavity. Critical reviews in oral biology and medicine : an official publication of the American Association of Oral Biologists. 1994; 5(2):159185.

25. Berkower AS, Biller HF. Head and neck cancer associated with Bloom's syndrome. Laryngoscope. 1988; 98(7):746-748. [PubMed: 3290604]

26. Hecht F, Hecht BK. Cancer in ataxia-telangiectasia patients. Cancer genetics and cytogenetics. 1990; 46(1):9-19. [PubMed: 2184934]

27. Snow DG, Campbell JB, Smallman LA. Fanconi's anaemia and post-cricoid carcinoma. The Journal of laryngology and otology. 1991; 105(2):125-127. [PubMed: 2013724]

28. Kutler DI, Auerbach AD, Satagopan J, et al. High incidence of head and neck squamous cell carcinoma in patients with Fanconi anemia. Arch Otolaryngol Head Neck Surg. 2003; 129(1):106112. [PubMed: 12525204]

29. Jones AS, Morar P, Phillips DE, et al. Second primary tumors in patients with head and neck squamous cell carcinoma. Cancer. 1995; 75(6):1343-1353. [PubMed: 7882285]

30. Leon X, Ferlito A, Myer CM 3rd, et al. Second primary tumors in head and neck cancer patients. Acta Otolaryngol. 2002; 122(7):765-778. [PubMed: 12484655]

31. Liao CT, Kang CJ, Chang JT, et al. Survival of second and multiple primary tumors in patients with oral cavity squamous cell carcinoma in the betel quid chewing area. Oral Oncol. 2007; 43(8):811819. [PubMed: 17174143]

32. Silverman S Jr, Gorsky M, Lozada F. Oral leukoplakia and malignant transformation. A follow-up study of 257 patients. Cancer. 1984; 53(3):563-568. [PubMed: 6537892]

33. Warnakulasuriya S, Johnson NW, van der Waal I. Nomenclature and classification of potentially malignant disorders of the oral mucosa. Journal of oral pathology \& medicine : official publication of the International Association of Oral Pathologists and the American Academy of Oral Pathology. 2007; 36(10):575-580.

34. Neville BW, Day TA. Oral cancer and precancerous lesions. CA: a cancer journal for clinicians. 2002; 52(4):195-215. [PubMed: 12139232]

35. Waldron CA, el-Mofty SK, Gnepp DR. Tumors of the intraoral minor salivary glands: a demographic and histologic study of 426 cases. Oral surgery, oral medicine, and oral pathology. 1988; 66(3):323-333.

36. Sobin, LH.; Gospodarowicz, MK.; Wittekind, C., editors. TNM Classification of Malignant Tumours. 7. 2009.

37. Robbins KT, Medina JE, Wolfe GT, et al. Standardizing neck dissection terminology. Official report of the Academy's Committee for Head and Neck Surgery and Oncology Archives of otolaryngology--head \& neck surgery. 1991; 117(6):601-605. [PubMed: 2036180]

38. Shah JP, Candela FC, Poddar AK. The patterns of cervical lymph node metastases from squamous carcinoma of the oral cavity. Cancer. 1990; 66(1):109-113. [PubMed: 2354399]

39. Fakih AR, Rao RS, Borges AM, et al. Elective versus therapeutic neck dissection in early carcinoma of the oral tongue. American journal of surgery. 1989; 158(4):309-313. [PubMed: 2802032]

40. Shah, JP.; Patel, SG.; Singh, B., et al. Jatin Shah's head and neck surgery and oncology. 4. Philadelphia, PA: Elsevier/Mosby; 2012.

41. McGregor AD, MacDonald DG. Routes of entry of squamous cell carcinoma to the mandible. Head \& neck surgery. 1988; 10(5):294-301. [PubMed: 3220769]

42. Brown JS, Lowe D, Kalavrezos N, et al. Patterns of invasion and routes of tumor entry into the mandible by oral squamous cell carcinoma. Head \& neck. 2002; 24(4):370-383. [PubMed: 11933179] 
43. McGregor AD, MacDonald DG. Patterns of spread of squamous cell carcinoma within the mandible. Head \& neck. 1989; 11(5):457-461. [PubMed: 2807886]

44. Woolgar JA, Scott J. Prediction of cervical lymph node metastasis in squamous cell carcinoma of the tongue/floor of mouth. Head \& neck. 1995; 17(6):463-472. [PubMed: 8847204]

45. Spiro RH, Huvos AG, Wong GY, et al. Predictive value of tumor thickness in squamous carcinoma confined to the tongue and floor of the mouth. American journal of surgery. 1986; 152(4):345350. [PubMed: 3766861]

46. Shah JP, Andersen PE. Evolving role of modifications in neck dissection for oral squamous carcinoma. The British journal of oral \& maxillofacial surgery. 1995; 33(1):3-8. [PubMed: 7718525]

47. Robbins KT, Ferlito A, Shah JP, et al. The evolving role of selective neck dissection for head and neck squamous cell carcinoma. European archives of oto-rhino-laryngology : official journal of the European Federation of Oto-Rhino-Laryngological Societies. 2013; 270(4):1195-1202.

48. Huang SH, Hwang D, Lockwood G, et al. Predictive value of tumor thickness for cervical lymphnode involvement in squamous cell carcinoma of the oral cavity: a meta-analysis of reported studies. Cancer. 2009; 115(7):1489-1497. [PubMed: 19197973]

49. Farr HW, Arthur K. Epidermoid carcinoma of the mouth and pharynx 1960-1964. The Journal of laryngology and otology. 1972; 86(3):243-253. [PubMed: 5014916]

50. Shoaib T, Soutar DS, MacDonald DG, et al. The accuracy of head and neck carcinoma sentinel lymph node biopsy in the clinically N0 neck. Cancer. 2001; 91(11):2077-2083. [PubMed: $11391588]$

51. Ross GL, Soutar DS, MacDonald G, et al. Sentinel node biopsy in head and neck cancer: preliminary results of a multicenter trial. Ann Surg Oncol. 2004; 11(7):690-696. [PubMed: 15197011]

52. Alkureishi LWT, Ross GL, Shoaib T, et al. Sentinel Node Biopsy in Head and Neck Squamous Cell Cancer: 5-Year Follow-Up of a European Multicenter Trial. Ann Surg Oncol. 2010; 17(9):24592464. [PubMed: 20552410]

53. Civantos FJ, Zitsch RP, Schuller DE, et al. Sentinel lymph node biopsy accurately stages the regional lymph nodes for T1-T2 oral squamous cell carcinomas: results of a prospective multiinstitutional trial. Journal of clinical oncology : official journal of the American Society of Clinical Oncology. 2010; 28(8):1395-1400. [PubMed: 20142602]

54. Ross GL, Shoaib T, Soutar DS, et al. The First International Conference on sentinel node biopsy in mucosal head and neck cancer and adoption of a multicenter trial protocol. Ann Surg Oncol. 2002; 9(4):406-410. [PubMed: 11986194]

55. Tupchong L, Scott CB, Blitzer PH, et al. Randomized study of preoperative versus postoperative radiation therapy in advanced head and neck carcinoma: long-term follow-up of RTOG study 7303. International journal of radiation oncology, biology, physics. 1991; 20(1):21-28.

56. Spiro JD, Spiro RH, Shah JP, et al. Critical assessment of supraomohyoid neck dissection. American journal of surgery. 1988; 156(4):286-289. [PubMed: 3177752]

57. Huang SF, Kang CJ, Lin CY, et al. Neck treatment of patients with early stage oral tongue cancer: comparison between observation, supraomohyoid dissection, and extended dissection. Cancer. 2008; 112(5):1066-1075. [PubMed: 18246535]

58. Andersen PE, Shah JP, Cambronero E, et al. The role of comprehensive neck dissection with preservation of the spinal accessory nerve in the clinically positive neck. American journal of surgery. 1994; 168(5):499-502. [PubMed: 7977984]

59. Hidalgo DA, Disa JJ, Cordeiro PG, et al. A review of 716 consecutive free flaps for oncologic surgical defects: refinement in donor-site selection and technique. Plastic and reconstructive surgery. 1998; 102(3):722-732. discussion 733-724. [PubMed: 9727437]

60. Schusterman MA, Miller MJ, Reece GP, et al. A single center's experience with 308 free flaps for repair of head and neck cancer defects. Plastic and reconstructive surgery. 1994; 93(3):472-478. discussion 479-480. [PubMed: 8115501]

61. Urken ML, Buchbinder D, Weinberg H, et al. Functional evaluation following microvascular oromandibular reconstruction of the oral cancer patient: a comparative study of reconstructed and nonreconstructed patients. The Laryngoscope. 1991; 101(9):935-950. [PubMed: 1886442] 
62. Hanasono MM, Friel MT, Klem C, et al. Impact of reconstructive microsurgery in patients with advanced oral cavity cancers. Head \& neck. 2009; 31(10):1289-1296. [PubMed: 19373778]

63. Zelefsky MJ, Harrison LB, Fass DE, et al. Postoperative radiation therapy for squamous cell carcinomas of the oral cavity and oropharynx: impact of therapy on patients with positive surgical margins. International journal of radiation oncology, biology, physics. 1993; 25(1):17-21.

64. Bartelink H, Breur K, Hart G, et al. The Value of Postoperative Radiotherapy as an Adjuvant to Radical Neck Dissection. Cancer. 1983; 52(6):1008-1013. [PubMed: 6883267]

65. Cooper JS, Pajak TF, Forastiere AA, et al. Postoperative concurrent radiotherapy and chemotherapy for high-risk squamous-cell carcinoma of the head and neck. New Engl J Med. 2004; 350(19):1937-1944. [PubMed: 15128893]

66. Bernier J, Domenge C, Ozsahin M, et al. Postoperative irradiation with or without concomitant chemotherapy for locally advanced head and neck cancer. New Engl J Med. 2004; 350(19):19451952. [PubMed: 15128894]

67. Lin K, Patel SG, Chu PY, et al. Second primary malignancy of the aerodigestive tract in patients treated for cancer of the oral cavity and larynx. Head \& neck. 2005; 27(12):1042-1048. [PubMed: 16265657]

68. Leon X, Martinez V, Lopez M, et al. Second, third, and fourth head and neck tumors. A progressive decrease in survival. Head \& neck. 2012; 34(12):1716-1719. [PubMed: 22307753]

69. Silverman S Jr, Rankin KV. Oral and pharyngeal cancer control through continuing education. Journal of cancer education : the official journal of the American Association for Cancer Education. 2010; 25(3):277-278. [PubMed: 20204576]

70. Foy JP, Bertolus C, William WN Jr, et al. Oral premalignancy: the roles of early detection and chemoprevention. Otolaryngologic clinics of North America. 2013; 46(4):579-597. [PubMed: 23910471]

71. Edge, SB. American Joint Committee on Cancer. AJCC cancer staging manual. 7. New York: Springer; 2010.

72. Loree TR, Strong EW. Significance of positive margins in oral cavity squamous carcinoma. American journal of surgery. 1990; 160(4):410-414. [PubMed: 2221245]

73. Chen YK, Huang HC, Lin LM, et al. Primary oral squamous cell carcinoma: an analysis of 703 cases in southern Taiwan. Oral oncology. 1999; 35(2):173-179. [PubMed: 10435152]

74. Funk GF, Karnell LH, Robinson RA, et al. Presentation, treatment, and outcome of oral cavity cancer: a National Cancer Data Base report. Head \& neck. 2002; 24(2):165-180. [PubMed: 11891947]

75. Carvalho AL, Ikeda MK, Magrin J, et al. Trends of oral and oropharyngeal cancer survival over five decades in 3267 patients treated in a single institution. Oral oncology. 2004; 40(1):71-76. [PubMed: 14662418]

76. Yeole BB, Sankaranarayanan R, Sunny MSL, et al. Survival from head and neck cancer in Mumbai (Bombay), India. Cancer. 2000; 89(2):437-444. [PubMed: 10918177]

77. Rogers SN, Brown JS, Woolgar JA, et al. Survival following primary surgery for oral cancer. Oral oncology. 2009; 45(3):201-211. [PubMed: 18674959]

78. Listl S, Jansen L, Stenzinger A, et al. Survival of patients with oral cavity cancer in Germany. PloS one. 2013; 8(1):e53415. [PubMed: 23349710] 


\section{Key Points}

- $\quad$ Cancer of the oral cavity is a common malignancy in the United States and around the world.

- The standard of care is primary surgical resection with or without postoperative adjuvant therapy.

- Multidisciplinary treatment is crucial to improve the oncologic and functional results in oral cancer patients

- $\quad$ Primary and secondary prevention of oral cancer requires education about lifestyle-related risk factors, and improved awareness and tools for early diagnosis. 


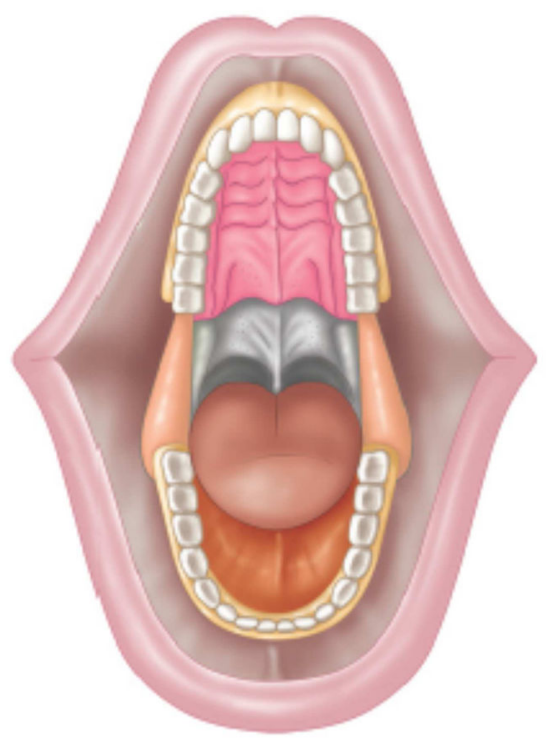

$$
\begin{aligned}
& \text { Lip ( upper and lower) } \\
& \text { Tongue (anterior } 2 / 3^{\text {nds }} \text { ) } \\
& \text { Floor of mouth } \\
& \text { Gingiva (upper and lower) } \\
& \text { Buccal mucosa } \\
& \text { Retromolar trigone } \\
& \text { Hard palate }
\end{aligned}
$$

Figure 1.

Anatomic sites of the oral cavity

From Shah JP, Patel SG, Singh B, et al. Jatin Shah's head and neck surgery and oncology. 4th ed. Philadelphia, PA: Elsevier/Mosby; 2012, 232-244 with permisison. 
Incidence ASR

Both sexes

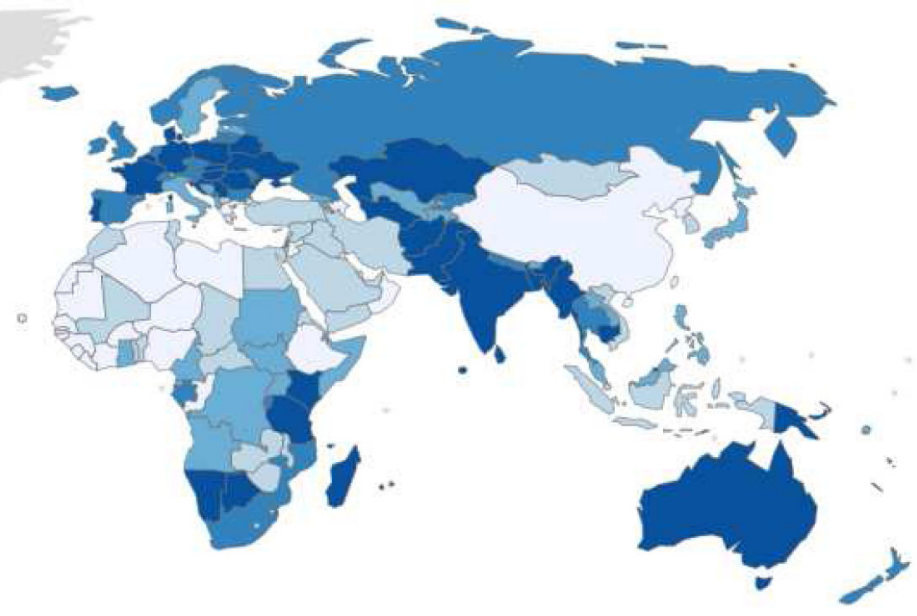

Source: GLOBOCAN 2012 (LARC)

Figure 2.

Incidence of oral cavity cancer among both sexes expressed by level of Age-standardized rate (ASR) in countries of the world (From GLOBOCAN 2012 International Agency for Research on Cancer (http://globocan.iarc.fr/Pages/Map.aspx.)) 


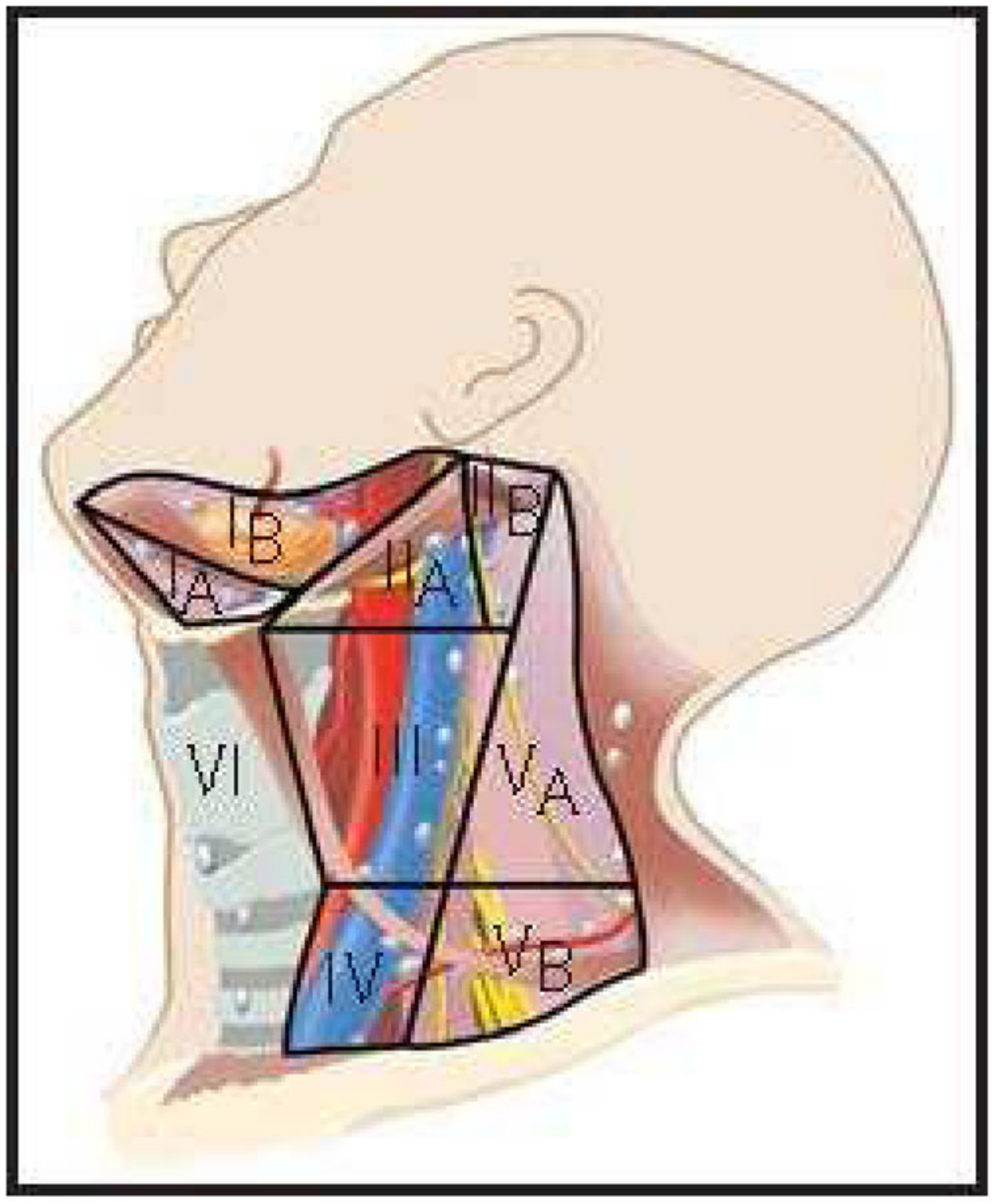

Figure 3.

Cervical lymph node level classification

From Shah JP, Patel SG, Singh B, et al. Jatin Shah's head and neck surgery and oncology. 4th ed. Philadelphia, PA: Elsevier/Mosby; 2012, 232-244, with permisison. 


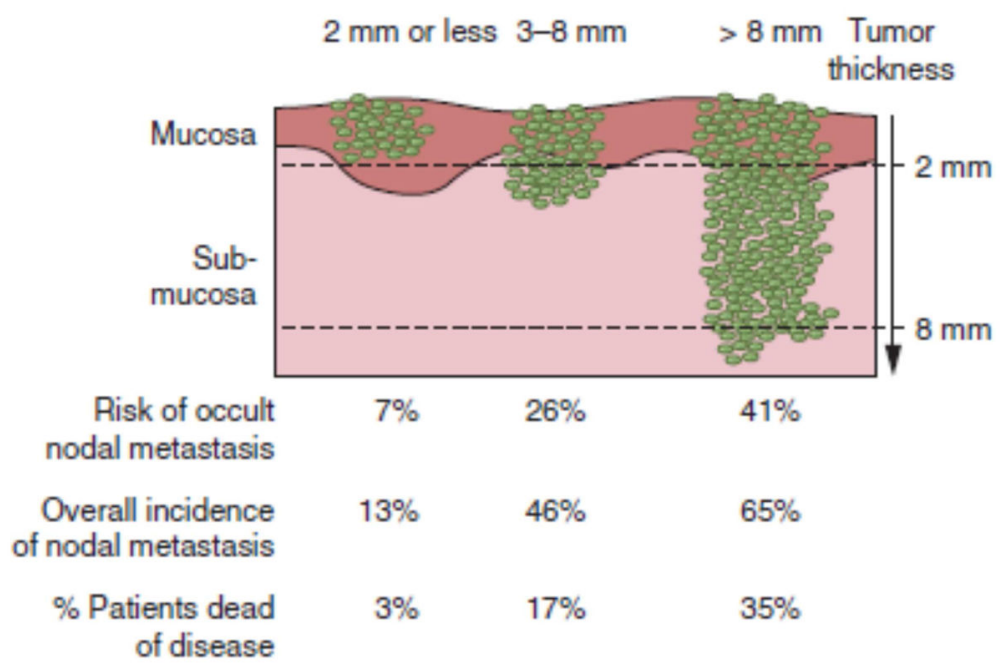

Figure 4.

Incidence of lymph node metastasis and survival stratified by the thickness of the primary tumor. (From Shah JP, Patel SG, Singh B, et al. Jatin Shah's head and neck surgery and oncology. 4th ed. Philadelphia, PA: Elsevier/Mosby; 2012, 232-244, with permisison.) 
A
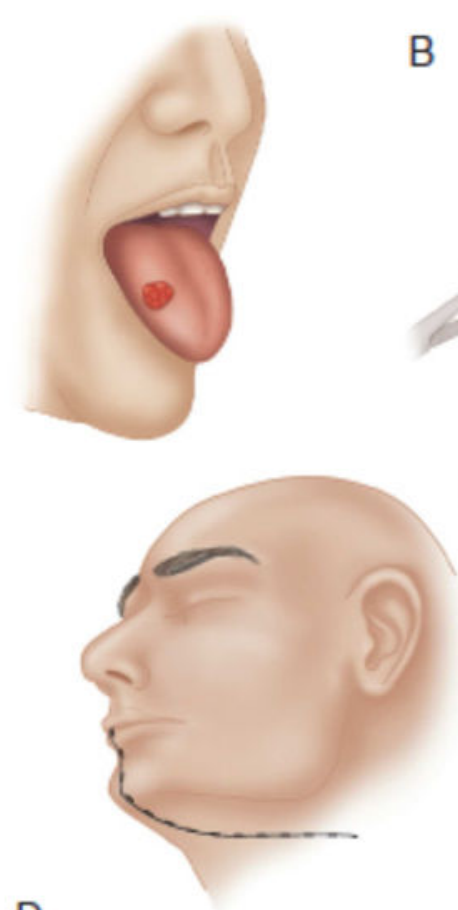

D

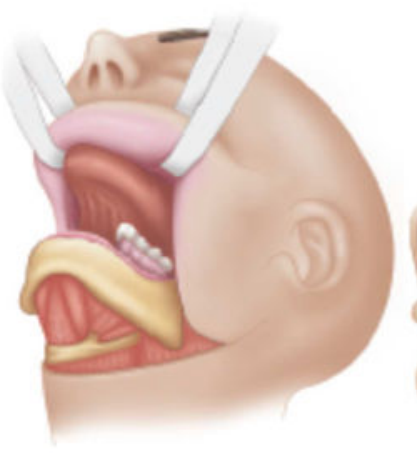

E

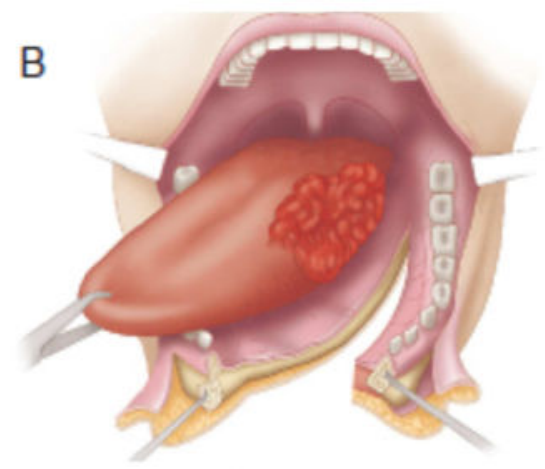

$\mathrm{C}$

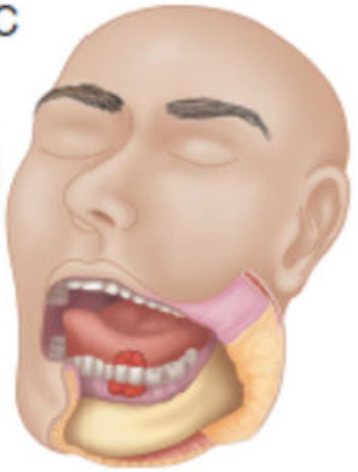

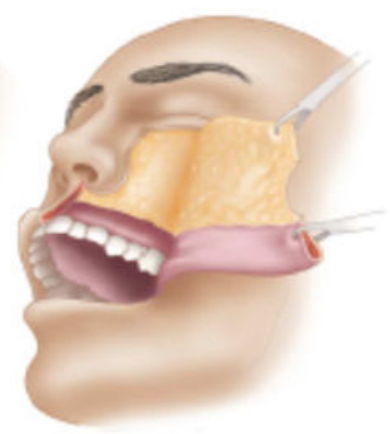

Figure 5.

Various surgical approaches. A, Peroral. B, Mandibulotomy. C, Lower cheek flap. D, Visor flap. E, Upper cheek flap. (From Shah JP, Patel SG, Singh B, et al. Jatin Shah's head and neck surgery and oncology. 4th ed. Philadelphia, PA: Elsevier/Mosby; 2012, 232-244, with permisison.) 


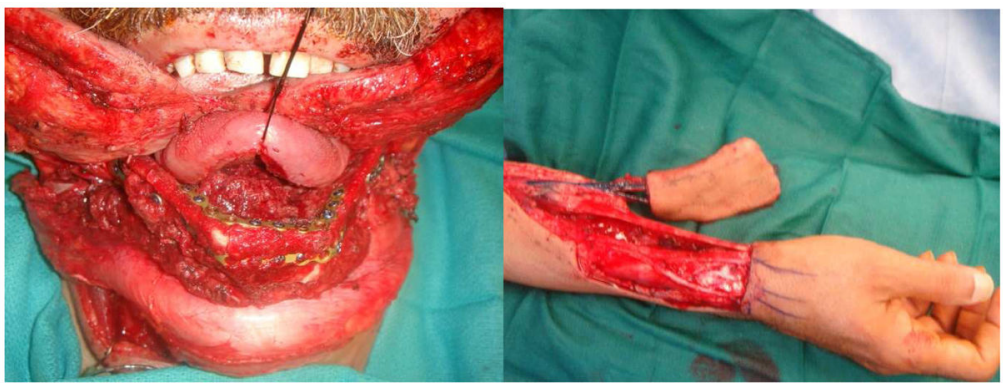

Figure 6.

Fibular (left) and radial forearm (right) free flaps are two of the most common flaps used in oral cavity reconstruction after major resections. 


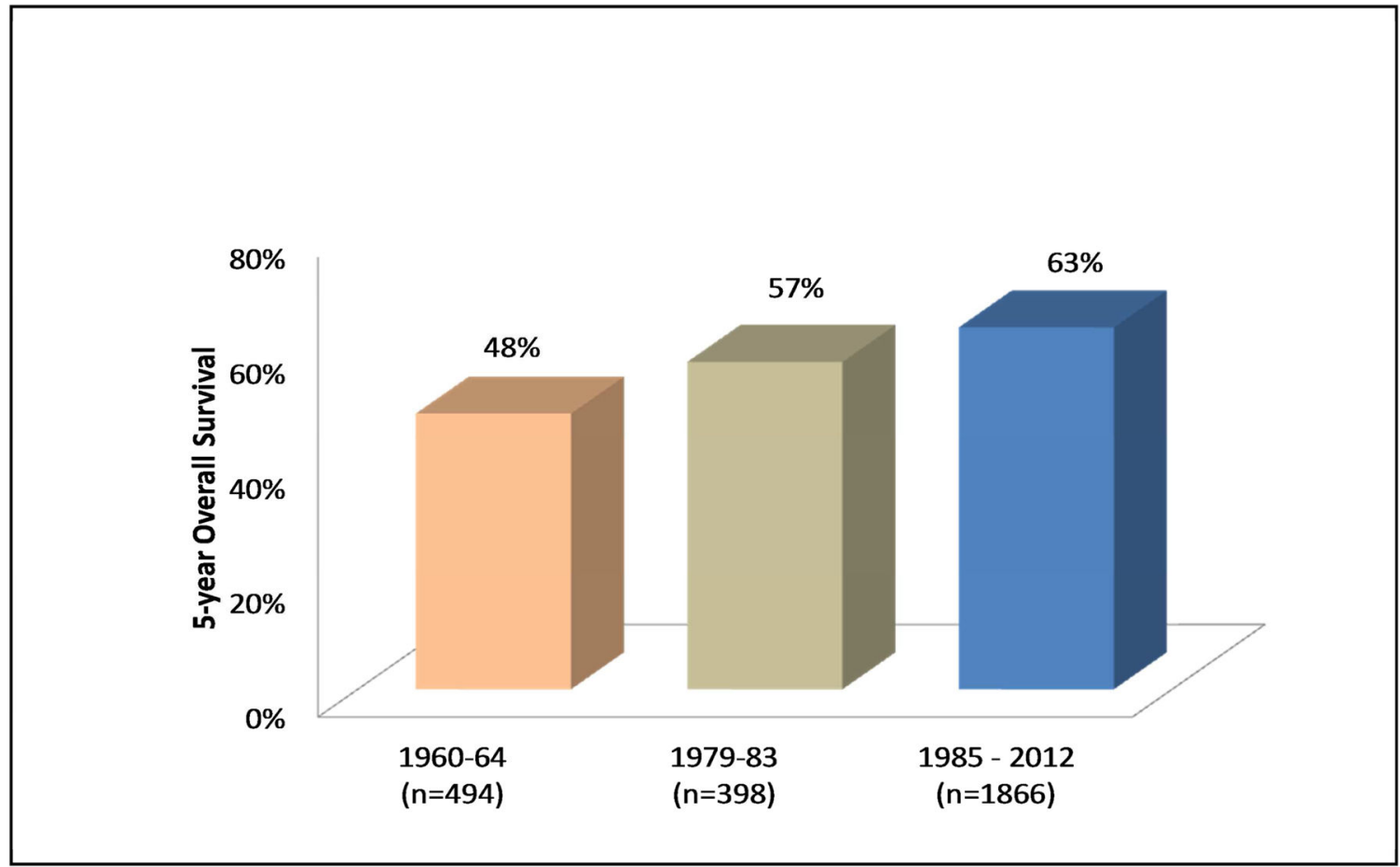

Figure 7.

Outcomes of treatment of SCCOC in three cohorts treated during different time periods at Memorial Sloan-Kettering Cancer Center (1960-2005). Courtesy of Memorial SloanKettering database, New York, NY. 


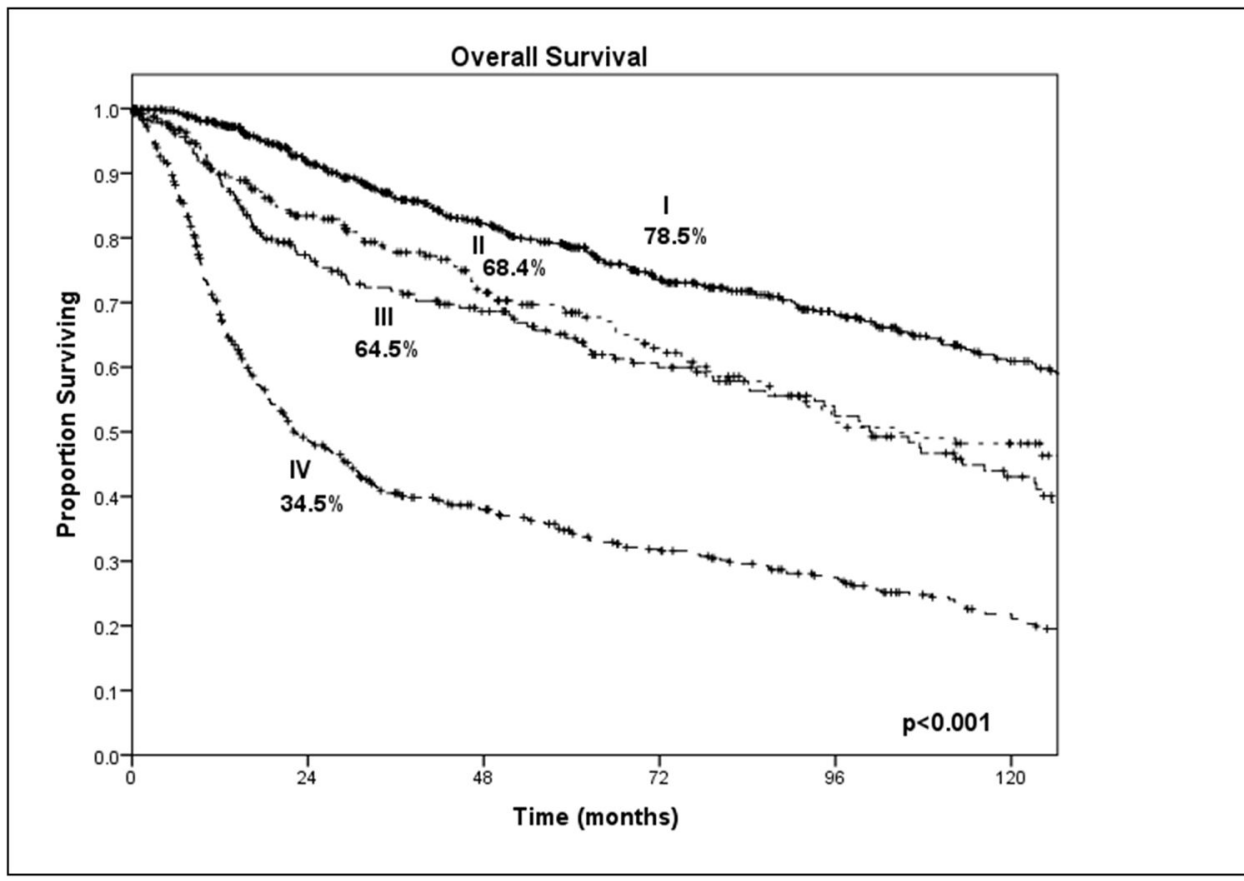

Figure 8.

Clinical stage at presentation is an important predictor of outcome. Courtesy of Memorial Sloan-Kettering database, New York, NY. 


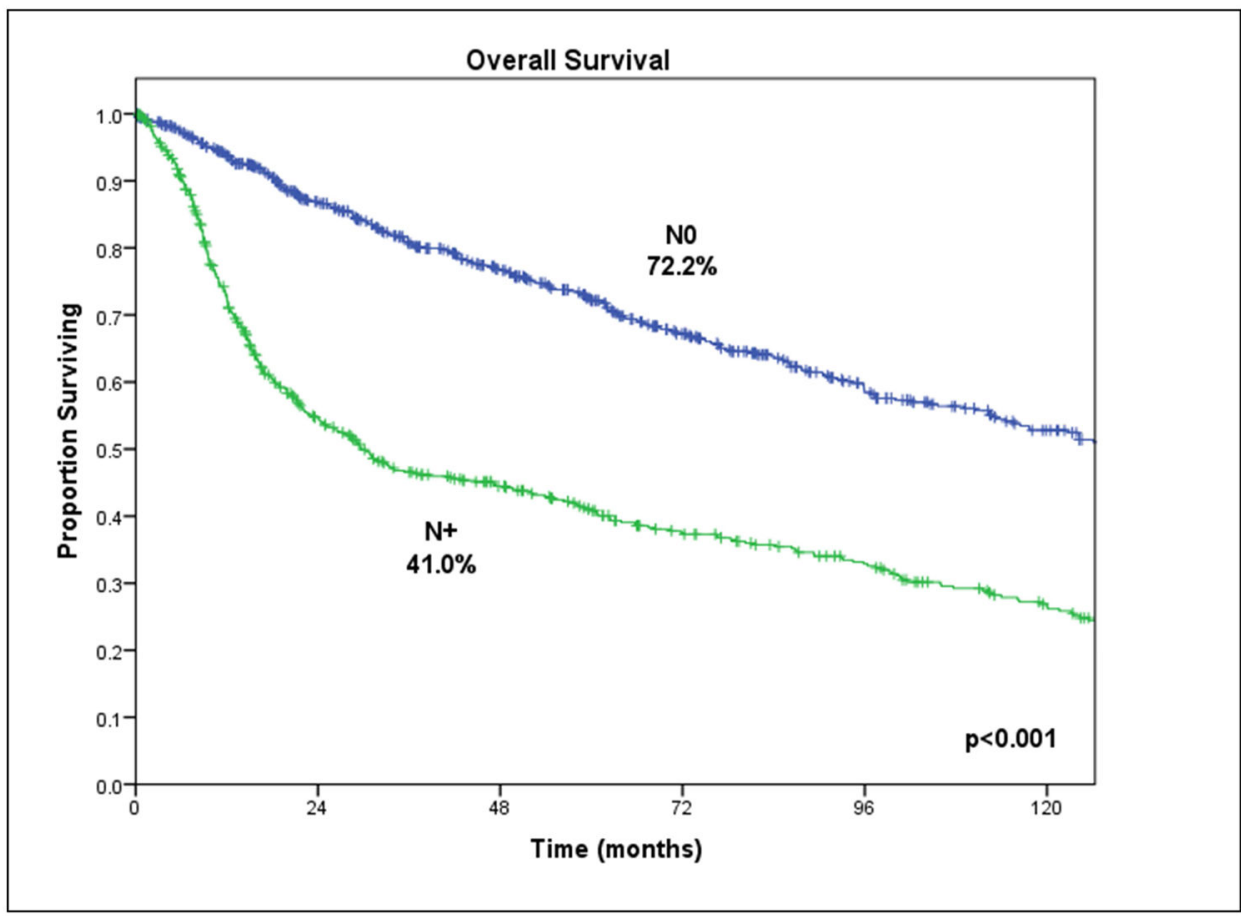

Figure 9.

Impact of clinically palpable lymph node metastasis on disease-specific survival in SCCOC. Courtesy of Memorial Sloan-Kettering database, New York, NY. 


\section{Table 1}

TNM classification of carcinomas of the oral cavity

T-Primary tumor

TX

T0

Primary tumor cannot be assessed

Tis

No evidence of primary tumor

Carcinoma in situ

T1

Tumor $2 \mathrm{~cm}$ or less in greatest dimension

$\mathrm{T} 2$

Tumor more than $2 \mathrm{~cm}$ but not more than $4 \mathrm{~cm}$ in greatest dimension

$\mathrm{T} 3$

Tumor more than $4 \mathrm{~cm}$ in greatest dimension

T4a (lip)

Tumor invades through cortical bone, inferior alveolar nerve, floor of mouth, or skin (chin or nose)

T4a (oral cavity)

Tumor invades through cortical bone, into deep/extrinsic muscle of tongue (genioglossus, hyoglossus, palatoglossus, and styloglossus), maxillary sinus, or skin of face

T4b (lip and oral cavity) Tumor invades masticator space, pterygoid plates, or skull base; or encases internal carotid artery

Note: Superficial erosion alone of bone/tooth socket by gingival primary is not sufficient to classify a as T4.

\section{N - Regional Lymph Nodes}

NX

NO

N1

$\mathrm{N} 2$

$\mathrm{N} 2 \mathrm{a}$

$\mathrm{N} 2 \mathrm{~b}$

$\mathrm{N} 2 \mathrm{c}$

$\mathrm{N} 3$
Regional lymph nodes cannot be assessed

No regional lymph node metastasis

Metastasis in a single ipsilateral lymph node, $3 \mathrm{~cm}$ or less in greatest dimension

Metastasis as specified in N2a, 2b, 2c below

Metastasis in a single ipsilateral lymph node, more than $3 \mathrm{~cm}$ but not more than $6 \mathrm{~cm}$ in greatest dimension

Metastasis in multiple ipsilateral lymph nodes, none more than $6 \mathrm{~cm}$ in greatest dimension

Metastasis in bilateral or contralateral lymph nodes, none more than $6 \mathrm{~cm}$ in greatest dimension

Metastasis in a lymph node more than $6 \mathrm{~cm}$ in greatest dimension

Note: Midline nodes are considered ipsilateral nodes.

M - Distant metastasis

MX Distant metastasis cannot be assessed

M0 No distant metastasis

M1 Distant metastasis

From, Edge SB, Byrd DR, Compton CC, eds. AJCC Cancer Staging Manual. 7th ed. New York, NY.: Springer, 2010; 33, with permission. 


\section{Table 2}

\begin{tabular}{|c|c|c|c|c|}
\hline \multicolumn{5}{|c|}{ ral cancer staging } \\
\hline \multirow{6}{*}{ 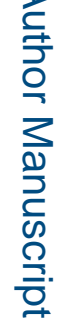 } & Stage & $T$ & $\mathbf{N}$ & M \\
\hline & 0 & Tis & \begin{tabular}{|l|} 
No \\
\end{tabular} & M0 \\
\hline & I & $\mathrm{T} 1$ & No & M0 \\
\hline & II & $\mathrm{T} 2$ & N0 & M0 \\
\hline & \multirow[t]{4}{*}{ III } & T3 & \begin{tabular}{|l|} 
No \\
\end{tabular} & M0 \\
\hline & & $\mathrm{T} 1$ & \begin{tabular}{|l|} 
N1 \\
\end{tabular} & M0 \\
\hline \multirow{11}{*}{ 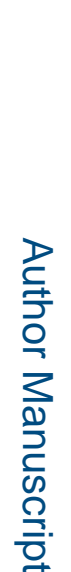 } & & $\mathrm{T} 2$ & N1 & M0 \\
\hline & & T3 & N1 & M0 \\
\hline & \multirow[t]{6}{*}{ IVA } & T4a & \begin{tabular}{|l|} 
No \\
\end{tabular} & M0 \\
\hline & & $\mathrm{T} 4 \mathrm{a}$ & N1 & M0 \\
\hline & & $\mathrm{T} 1$ & N2 & M0 \\
\hline & & $\mathrm{T} 2$ & N2 & M0 \\
\hline & & $\mathrm{T} 3$ & N2 & M0 \\
\hline & & $\mathrm{T} 4 \mathrm{a}$ & N2 & M0 \\
\hline & IVB & Any $T$ & N3 & M0 \\
\hline & & $\mathrm{T} 4 \mathrm{~b}$ & Any N & M0 \\
\hline & IVC & Any $\mathrm{T}$ & Any N & M1 \\
\hline
\end{tabular}

From, Edge SB, Byrd DR, Compton CC, eds. AJCC Cancer Staging Manual. 7th ed. New York, NY.: Springer, 2010; 33, with permission. 
Table 3

Indications for Segmental mandibulectomy

Gross invasion of the of the mandible

Tumor fixation to the majority of the vertical height of the occlusal surface of the mandible in hypoplastic edentulous mandible with significant loss of vertical height precluding safe performance of rim resection

Tumor fixed to the mandible following prior radiotherapy to the mandible 


\section{Table 4}

Risk factors of nodal metastasis in oral cancer

\begin{tabular}{ll}
\hline$\cdot$ & Tumor Size \\
• & Histologic Grade \\
• & Depth of Invasion \\
• & Perineural Invasion \\
\hline
\end{tabular}




\section{Table 5}

Types of Neck Dissections

\begin{tabular}{|c|c|c|c|}
\hline $\begin{array}{l}\text { Radical Neck Dissection } \\
\text { (RND) }\end{array}$ & $\begin{array}{l}\text { Lymph Nodes Excised } \\
\text { Levels I-V }\end{array}$ & $\begin{array}{l}\text { Other Structures Excised } \\
\text { Sternocleidomast oid Muscle, Internal } \\
\text { Jugular Vein, Spinal Accessory Nerve, } \\
\text { Submandibular Gland }\end{array}$ & Structures Preserved \\
\hline $\begin{array}{l}\text { Modified Radical Neck } \\
\text { Dissection (MRND) Type I }\end{array}$ & Levels I-V & $\begin{array}{l}\text { Sternocleidomast oid Muscle, Internal } \\
\text { Jugular Vein, Submandibular Gland }\end{array}$ & Spinal Accessory Nerve \\
\hline $\begin{array}{l}\text { Modified Radical Neck } \\
\text { Dissection (MRND) Type II }\end{array}$ & Levels I-V & $\begin{array}{l}\text { Internal Jugular Vein, Submandibular } \\
\text { Gland }\end{array}$ & $\begin{array}{l}\text { Sternocleidomoid Muscle, Spinal } \\
\text { Accessory Nerve }\end{array}$ \\
\hline $\begin{array}{l}\text { Modified Radical Neck } \\
\text { Dissection (MRND) Type III }\end{array}$ & Levels I-V & Submandibular Gland & $\begin{array}{l}\text { Sternocleidomast oid Muscle, } \\
\text { Internal Jugular Vein, Spinal } \\
\text { Accessory Nerve }\end{array}$ \\
\hline $\begin{array}{l}\text { Supraomohyoid Neck } \\
\text { Dissection (SOHND) }\end{array}$ & Levels I-III & Submandibular Gland & $\begin{array}{l}\text { Sternocleidomast oid Muscle, } \\
\text { Internal Jugular Vein, Spinal } \\
\text { Accessory Nerve }\end{array}$ \\
\hline
\end{tabular}


